\title{
Banking relationship numbers and new business bankruptcies
}

\author{
Yuta Ogane
}

Accepted: 24 October 2015/Published online: 11 November 2015

(C) The Author(s) 2015. This article is published with open access at Springerlink.com

\begin{abstract}
This paper examines the effect of the number of correspondent financial institutions for small and medium-sized enterprises (SMEs) at the first settlement of accounts on subsequent firm bankruptcy risk using survival models. We use a unique firm-level data set of 2667 unlisted SMEs incorporated in Japan between April 2003 and December 2009. Moreover, in the nature of the analysis, we focus on firms that transact with at least one financial institution and disclose information about profit at the first settlement. We find that more correspondent financial institutions for SMEs at the first settlement increase subsequent firm bankruptcy risk. Furthermore, we check the robustness of this result with the method of instrumental variables (IV methods) and obtain similar results; in other words, the risk of firm bankruptcy increases with the number of correspondent financial institutions.
\end{abstract}

Keywords Correspondent financial institutions · Multiple bank relationships - Bankruptcy $\cdot$ Small and medium-sized enterprises

JEL Classifications $\quad \mathrm{G} 21 \cdot \mathrm{G} 33 \cdot \mathrm{L} 26 \cdot \mathrm{M} 13 \cdot$ M21

Y. Ogane $(\varangle)$

Graduate School of Economics, Nagoya University, Furocho, Chikusa-ku, Nagoya, Aichi 464-8601, Japan

e-mail: ogane.yuta@e.mbox.nagoya-u.ac.jp

\section{Introduction}

As indicated by Carter and Van Auken (2006) and Franco and Haase (2010), business continuity for small and medium-sized enterprises (SMEs) largely depends on whether they receive sufficient support from their correspondent financial institutions. However, the strategies available to SMEs to receive support from financial institutions are limited. In reality, they cannot actively address the problems that hinder support from financial institutions, such as asymmetric information and incomplete contracts. In addition, it is difficult for SMEs to prove that they are promising enterprises and attract investment from financial institutions.

However, there are strategies that SMEs can proactively control, and the choice of the number of correspondent financial institutions is one such example. In most cases, the right to decide the number of correspondent financial institutions rests not with financial institutions but with client firms. Numerous studies have examined the choice of the number of correspondent financial institutions as this is an important part of the business strategy of SMEs and entrepreneurs.

Here, we review the literature on the subject of the number of correspondent financial institutions, including multiple bank relationships. First, we begin with how multiple bank relationships affect hold-up problems and credit availability of firms. A single bank relationship causes an information monopoly by a 
specific financial institution, and thus causes hold-up problems (Sharpe 1990; Rajan 1992). In addition, multiple bank relationships worsen firms' credit availability (Petersen and Rajan 1994; Ongena and Smith 2000). However, Ongena and Smith (2000) also show that multiple bank relationships can reduce the hold-up problems. Moreover, Hernández-Cánovas and Martínez-Solano (2007) argue that the SMEs that transact with fewer financial intermediaries have more financial restraints.

Next, we review the literature on the theoretical risks of firm bankruptcy. Multiple bank relationships make it difficult for creditors to coordinate with each other, particularly in the case of business restructuring, and thus increase the risk for customer firms (Dewatripont and Maskin 1995; Bolton and Scharfstein 1996; Foglia et al. 1998; Brunner and Krahnen 2008). In contrast, some studies have shown that multiple bank relationships reduce the theoretical firm bankruptcy risk. For example, Detragiache et al. (2000) show that multiple bank relationships can ensure a more stable supply of credit and reduce the probability of an early liquidation of the project. Furthermore, Guiso and Minetti (2010) find a negative correlation between borrowing differentiation and restructuring costs.

These studies examine the impact of multiple bank relationships on hold-up problems, credit availability of firms, and theoretical firm bankruptcy risk. However, the more important thing for the business manager is the actual business performance. Of course, there exist studies on the relationship between the number of correspondent financial institutions and business performance. For instance, Degryse and Ongena (2001) investigate the effects of multiple bank relationships on sales profitability employing a sample of listed firms and find a negative correlation between the two. Furthermore, Castelli et al. (2012) examine how the number of bank relationships affects firm performance using a unique data set of Italian small firms and indicate that an increase in the number of correspondent financial institutions reduces firms' financial performance, such as the return on equity and return on assets.

As shown above, some studies describe the relationship between the number of correspondent financial institutions and business performance. However, to the best of our knowledge, no study has empirically examined the impact of the number of correspondent financial institutions on firm bankruptcy in spite of its importance. For this reason, this paper empirically investigates the effect of the number of correspondent financial institutions on firms' subsequent bankruptcy risk. ${ }^{1}$ In addition, it uses unlisted SMEs just after incorporation as the sample because of the following reason: as referred in many studies, such as Mata (1994) and Song et al. (2008), firms are most likely to go bankrupt within a few years of incorporation; thus, clarifying the effect during this period is important in terms of providing a new strategy for business managers and entrepreneurs to avoid bankruptcy in the early stages of the entrepreneurial process.

In sum, this paper empirically examines the effect of the number of correspondent financial institutions at the incorporation of the firms on their subsequent bankruptcy risk. This paper is the first to empirically investigate how the number of correspondent financial institutions affects firm bankruptcy, and this paper is clearly distinguished from the previous studies as it provides empirical evidence on firm bankruptcy, focusing on firms just after incorporation. We expect that more correspondent financial institutions increase subsequent firm bankruptcy risk because of the following two reasons.

First, previous studies such as Degryse and Ongena (2001) and Castelli et al. (2012) show that an increase in the number of correspondent financial institutions reduces firm performance. This result suggests that the higher the number of correspondent financial institutions, the greater is the risk of subsequent firm bankruptcy. Second, as new firms are very fragile, the case of using only new firms corresponds to the situation described in the theoretical model based on Olson (1965) and Osborne (2003). ${ }^{2}$ This model predicts that an increase in the number of correspondent financial institutions increases the risk of firm bankruptcy, and it is not unrealistic to assume that new firms are frequently faced with the situation with high risk of bankruptcy as shown by the model.

As expected, we find that more correspondent financial institutions for SMEs at the first settlement

\footnotetext{
$\overline{1}$ Mayer (1988) shows that banks play important roles in firms' bankruptcy avoidance. Moreover, Hoshi et al. (1990), Grunert and Weber (2009), Shimizu (2012), Gambini and Zazzaro (2013), and Han et al. (2014) show the possibility that close firm-bank relationships improve business performance and prevent firms from going bankrupt.

2 For further details, see the "Appendix".
} 
of accounts increase the subsequent firm bankruptcy risk. In addition, we obtain similar results when we substitute a multiple bank relationships dummy variable for the number of correspondent financial institutions; specifically, we find that multiple bank relationships also increase subsequent firm bankruptcy risk.

The remainder of the paper is organized as follows. Section 2 introduces the data used in this paper. Section 3 presents the results of the regression analyses. Section 4 checks the robustness of the results obtained in Sect. 3. Section 5 concludes the paper.

\section{Data}

We use a unique firm-level data set collected by Tokyo Shoko Research, Ltd. (TSR), one of the largest credit reporting agencies in Japan. This data set comprises the TSR Enterprise Information File, TSR Bankrupt Information File, and TSR Manager Information File. We target firms incorporated in Japan between April 2003 and December 2009 that are unlisted and have a capital of less than 50 million yen. ${ }^{3}$ Moreover, we use the data of the first settlement of accounts of these firms, and in keeping with the nature of the analysis, we focus on firms that transact with at least one financial institution and disclose information about profit at the first settlement. In this paper, we define the number of financial institutions recorded in the list of bank names in the TSR Enterprise Information File as the number of correspondent financial institutions for the firms.

Here, we elaborate on this data set. To begin with, we classify the firms as either continuing or bankrupt based on whether they go bankrupt within 5 years from the first settlement, and thus there are 2541 continuing firms and 126 bankrupt firms. These 2667 firms represent almost all of the firms that meet the above data extraction conditions in the TSR Enterprise Information File. Therefore, the bias associated with sample extraction is likely to be small. Moreover, these data are censored up to 5 years after the first settlement.

Table 1 shows the distribution of the sample firms, and Fig. 1 shows the distribution of the number of correspondent financial institutions. The firm age in

\footnotetext{
3 The date of establishment and that of incorporation do not necessarily concur. In this paper, from the sample, we exclude firms whose interval between establishment and incorporation exceeds 30 years.
}

this table shows the age of each firm at the first settlement and also represents the number of years from establishment to incorporation. Although not included in Table 1, we also obtain the following information. First, for both continuing and bankrupt firms, the minimum number of correspondent financial institutions is one, whereas the maximum is nine. In addition, the difference in the mean value of the number of correspondent financial institutions between the two groups is statistically significant at the $5 \%$ level. Moreover, as indicated in Fig. 1, the percentage of continuing firms that transact with multiple banks is $44.4 \%$, whereas that of bankrupt firms that transact with multiple banks is $54.0 \%$. The difference between the two is also statistically significant at the $5 \%$ level. Hence, the firms that go bankrupt within 5 years from the first settlement tend to have more correspondent financial institutions than firms that do not go bankrupt. On the other hand, the differences in the mean value of the profit and the capital between the two groups are statistically significant at the $10 \%$ level, whereas the difference in the mean value of firm age is not statistically significant. Therefore, there is not much difference in the characteristics between continuing and bankrupt firms, except for the number of correspondent financial institutions.

Furthermore, we also use the following aggregate data for each prefecture: Nihon Kinyu Meikan (the directory of Japanese financial institutions), published by Nihon Kinyu Tsushin Sha; the Population Estimates, published by the Bureau of Statistics of the Ministry of Internal Affairs and Communications; the Report on Prefectural Accounts, produced by the Cabinet Office; the Number of Prefectural Sorted Ordinary Corporation, published by the National Tax Agency; and ORBIS, provided by Bureau van Dijk. These data represent information about the prefectures where the sample firms belong to at the time of the first settlement.

\section{Empirical results}

In this section, we use survival models and examine the effect of the number of correspondent financial institutions for SMEs at the first settlement on the lifetime of the firms from their incorporation. From the perspective of robustness, we estimate the effect using both the Cox proportional hazards model and the Weibull proportional hazards model. Table 2 shows 
Table 1 Distribution of sample firms

\begin{tabular}{|c|c|c|c|c|c|c|c|c|c|}
\hline \multirow[t]{2}{*}{ Number of firms } & & \multicolumn{2}{|c|}{$\begin{array}{l}\text { Number of correspondent financial } \\
\text { institutions }\end{array}$} & \multicolumn{2}{|c|}{$\begin{array}{l}\text { Profit (in millions of } \\
\text { yen) }\end{array}$} & \multicolumn{2}{|c|}{$\begin{array}{l}\text { Capital (in billions of } \\
\text { yen) }\end{array}$} & \multicolumn{2}{|c|}{$\begin{array}{l}\text { Firm age (in } \\
\text { years) }\end{array}$} \\
\hline & & Mean & Median & Mean & Median & Mean & Median & Mean & Median \\
\hline Continuing firms & 2541 & 1.667 & 1 & 0.733 & 0.200 & 0.007 & 0.004 & 5.402 & 0.990 \\
\hline Bankrupt firms & 126 & 1.905 & 2 & -5.317 & 0.203 & 0.008 & 0.005 & 4.689 & 1.990 \\
\hline Total & 2667 & 1.678 & 1 & 0.447 & 0.200 & 0.007 & 0.004 & 5.368 & 0.990 \\
\hline
\end{tabular}
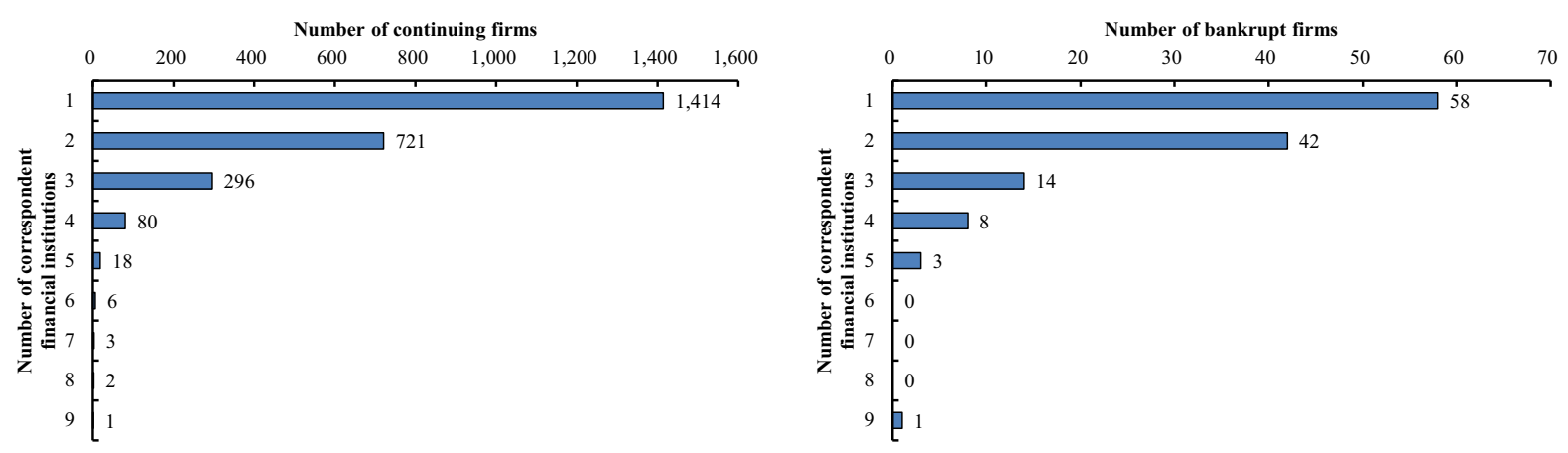

Fig. 1 Distribution of correspondent financial institutions

the definition and the source of each variable, and Table 3 details the descriptive statistics. ${ }^{4}$ The close relationship industries, which we control as a covariate, are a dummy variable that is equal to 1 if a firm is classified into the business type that has many opportunities to receive advice from its main bank or 0 otherwise, following Ogura (2007). ${ }^{5}$ In addition, the

\footnotetext{
"The minimum "time to bankruptcy" is -0.91 , but the firm that takes a negative value is only one out of 2667 , and we exclude this firm from the sample in the estimation. Moreover, the minimum "firm age" and "time to the first settlement" are also negative; however, the firms that take these values are very few, and thus these samples scarcely affect the results of the regression analyses.

${ }^{5}$ Ogura (2007) uses a unique firm-level data set of unlisted companies collected from the Survey of the Financial Environment of Enterprises, conducted by the Small and Medium Enterprise Agency in October 2002, and classifies target companies into two groups according to their business type. While one group has many opportunities to receive advice from their main banks, the other group has few opportunities to do so. To clarify the difference in the strength of the relationships, Ogura (2007) calls the former the close relationship industries, and adopts this as a dummy variable. The close relationship industries include wholesale, real estate, accommodation, some service industries (e.g., food and beverage), manufacturing (other than wooden products), chemical products, and electric machinery and appliances.
}

credit rating, which we also control as a covariate, is the indicator by which TSR comprehensively evaluates the firms based on four criteria: qualifications of the manager, growth potential, stability, and openness. Higher ratings imply that the firm is a prime enterprise. ${ }^{6}$ Industry and incorporation year dummy variables are also included in the regressions.

In the analyses in this paper, odd columns show the results when we use standard errors clustered by prefecture and settlement year, while even columns represent the results for the cases where we adopt standard errors clustered by firm, i.e., heteroskedasticity-robust standard errors.

Table 4 shows the results of the regression analyses. Columns 1 and 2 show the regression results from using the Cox proportional hazards model, and columns 3 and 4 show those from the Weibull proportional hazards model. As shown in columns 1-4, more correspondent financial institutions for SMEs at the first settlement increase the subsequent firm bankruptcy risk at the $5 \%$ significance level

\footnotetext{
${ }^{6}$ In the four viewpoints, stability occupies $45 \%$ of the total. Therefore, this variable mainly indicates the stability of each firm. In addition, stability is evaluated on owned capital, financial transactions, collateral margins, etc.
} 
Table 2 Definition and source of each variable

Variable name Definition

(A) Definition

Time to bankruptcy

Bankruptcy

Number of correspondent financial institutions

Multiple bank relationships

City bank

Regional bank

Shinkin bank

Capital

Firm age

Close relationship industries

Profit

Sales

Manager age

Offices Employees

Male

Credit rating

Time to the first settlement

Herfindahl index of financial institutions

Financial institutions

Population

GPP

Ordinary corporations

Economic growth rate

Startup rate

Variable name
Number of years from the first settlement of accounts to bankruptcy

Dummy variable that is equal to 1 if the firm goes bankrupt within 5 years of the first settlement of accounts or 0 otherwise

Number of correspondent financial institutions of each firm

Dummy variable that is equal to 1 if the firm opts for multiple bank relationships or 0 otherwise Dummy variable that is equal to 1 if the main bank of each firm is city bank or 0 otherwise

Dummy variable that is equal to 1 if the main bank of each firm is regional bank or 0 otherwise

Dummy variable that is equal to 1 if the main bank of each firm is Shinkin bank (Japanese smallscale bank) or 0 otherwise

Capital of each firm (unit: billion yen)

Age of each firm

Dummy variable that is equal to 1 if the firm is classified into the business type that has many opportunities to receive advice from its main bank or 0 otherwise

Profit of each firm (unit: million yen)

Sales amount of each firm (unit: thousand yen)

Age of the manager of each firm

Number of offices of each firm The number of employees of each firm

Dummy variable that is equal to 1 if the manager of the firm is male or 0 otherwise

Credit rating of each firm evaluated by Tokyo Shoko Research

Length of time from the incorporation to the first settlement of accounts

Herfindahl index of the number of financial institutions in each prefecture

Ratio of the number of financial institutions in each prefecture to the number of ordinary corporations

Population in each prefecture (unit: million)

Real gross prefectural product in each prefecture (unit: trillion yen)

Number of ordinary corporations in each prefecture (unit: million)

Growth rate of the real gross prefectural product in each prefecture

Startup rate of small and unlisted enterprises in each prefecture
(B) Source

Time to bankruptcy

Bankruptcy

Number of correspondent

financial institutions

Multiple bank relationships

City bank

Regional bank

Shinkin bank

Capital

Firm age

Close relationship industries

Profit

\section{Source}

TSR Enterprise Information File (Tokyo Shoko Research)

TSR Bankrupt Information File (Tokyo Shoko Research)

TSR Manager Information File (Tokyo Shoko Research) 
Table 2 continued

\begin{tabular}{ll}
\hline Variable name & Source \\
\hline Sales & \\
Manager age & \\
Offices & \\
Employees & \\
Male & \\
Credit rating & \\
Time to the first settlement & \\
Herfindahl index of financial & Nihon Kinyu Meikan (Nihon Kinyu Tsushin Sya) \\
institutions & Nihon Kinyu Meikan (Nihon Kinyu Tsushin Sya) and Number of Prefectural Sorted Ordinary \\
Financial institutions & Corporation (National Tax Agency) \\
Population & Population Estimates (Bureau of Statistics of the Ministry of Internal Affairs and \\
Communications) \\
$\begin{array}{l}\text { GPP } \\
\text { Ordinary corporations } \\
\text { Economic growth rate }\end{array}$ \\
$\begin{array}{l}\text { Startup rate } \\
\text { Number of Prefectural Sorted Ordinary Corporation (National Tax Agency) } \\
\text { Report on Prefectural Accounts (Cabinet Office) } \\
\text { ORBIS (Bureau van Dijk) and Number of Prefectural Sorted Ordinary Corporation (National }\end{array}$ \\
\hline
\end{tabular}

when we use standard errors clustered by prefecture and settlement year, whereas it is statistically significant at the $10 \%$ level when we adopt standard errors clustered by firm. Therefore, more correspondent financial institutions do not work as insurance for firms to avoid bankruptcy, as Detragiache et al. (2000) show; on the contrary, it increases the risk of bankruptcy, as other literature shows. As for other covariates except for the number of correspondent financial institutions in columns $1-4$, the profit and the economic growth rate are negatively associated with subsequent firm bankruptcy risk, while capital is positively associated with the risk.

Columns 5-8 represent the results when firms' other information is added to columns $1-4$. Indeed, the sample size decreases slightly because of data limitations, but there is a high possibility that the bias associated with sample extraction is small. In columns 5-8, we also control covariates that may affect firm bankruptcy, such as the number of offices and employees, and include the credit rating as a covariate that is a good predictor of the stability of firms. As these columns show, more correspondent financial institutions increase subsequent firm bankruptcy risk at the $1 \%$ significance level, regardless of the standard errors. In addition, although the capital and economic growth rate are statistically significant in columns 1-4, these covariates are not statistically significant in columns 5-8. In contrast, for all the firm age and the Herfindahl index of financial institutions are not statistically significant in columns $1-4$, these covariates are significant in columns 5-8. Furthermore, the credit rating is also statistically significant in columns 5-8; this indicates that the rating expresses the risk of firm bankruptcy well. Thus, the regressions in columns 5-8 can control the stability of firms to some extent.

In addition, Table 5 shows the results when we substitute a multiple bank relationships dummy variable for the number of correspondent financial institutions in Table 4. This table shows similar results to those in Table 4; specifically, multiple bank relationships at the first settlement also increase subsequent firm bankruptcy risk. This indicates that the result in Table 4 does not stem from the outliers in the sample and that there is a huge difference between the impact of a single bank relationship and that of multiple bank relationships on the risk.

In sum, more correspondent financial institutions for SMEs at their first settlement increase subsequent firm bankruptcy risk, and multiple bank relationships at the settlement also increase subsequent firm bankruptcy risk. 
Table 3 Descriptive statistics

\begin{tabular}{|c|c|c|c|c|c|c|}
\hline Variable name & $N$ & Mean & Median & SD & Min & Max \\
\hline Time to bankruptcy & 2667 & 5.554 & 5.980 & 0.863 & -0.910 & 6.000 \\
\hline Bankruptcy & 2622 & 0.035 & 0 & 0.185 & 0 & 1 \\
\hline Number of correspondent financial institutions & 2667 & 1.678 & 1 & 0.946 & 1 & 9 \\
\hline Multiple bank relationships & 2667 & 0.448 & 0 & 0.497 & 0 & 1 \\
\hline City bank & 2667 & 0.221 & 0 & 0.415 & 0 & 1 \\
\hline Regional bank & 2667 & 0.530 & 1 & 0.499 & 0 & 1 \\
\hline Shinkin bank & 2667 & 0.216 & 0 & 0.411 & 0 & 1 \\
\hline Capital & 2667 & 0.007 & 0.004 & 0.007 & 0.000 & 0.050 \\
\hline Firm age & 2667 & 5.368 & 0.990 & 7.455 & -0.010 & 30.000 \\
\hline Close relationship industries & 2667 & 0.333 & 0 & 0.471 & 0 & 1 \\
\hline Profit & 2667 & 0.447 & 0.200 & 16.632 & -350.000 & 226.766 \\
\hline Sales & 2622 & 161.459 & 56.681 & 454.028 & 0 & 9389.677 \\
\hline Manager age & 2622 & 46.836 & 46.978 & 10.489 & 18.038 & 85.967 \\
\hline Offices & 2622 & 0.477 & 0 & 1.447 & 0 & 23 \\
\hline Employees & 2622 & 8.319 & 4 & 19.899 & 1 & 490 \\
\hline Male & 2622 & 0.944 & 1 & 0.229 & 0 & 1 \\
\hline Credit rating & 2622 & 45.193 & 45 & 4.929 & 16 & 66 \\
\hline Time to the first settlement & 2622 & 0.749 & 0.980 & 0.455 & -1.000 & 3.980 \\
\hline Herfindahl index of financial institutions & 2667 & 0.120 & 0.104 & 0.073 & 0.035 & 0.322 \\
\hline Financial institutions & 2667 & 0.935 & 0.957 & 0.359 & 0.388 & 1.901 \\
\hline Population & 2667 & 5.077 & 3.793 & 3.955 & 0.596 & 13.048 \\
\hline GPP & 2667 & 26.243 & 17.071 & 30.405 & 2.040 & 102.042 \\
\hline Ordinary corporations & 2667 & 142.968 & 76.220 & 172.939 & 9.416 & 587.825 \\
\hline Economic growth rate & 2667 & 1.338 & 1.482 & 2.461 & -9.149 & 8.675 \\
\hline Startup rate & 2667 & 3.204 & 3.118 & 0.982 & 1.063 & 7.018 \\
\hline
\end{tabular}

The unit of sales is million yen

\section{Robustness checks}

In the previous section, we obtained the result that more correspondent financial institutions for SMEs at the first settlement increase subsequent firm bankruptcy risk. However, we cannot deny the possibility that the result is due to reverse causality. In other words, firms that are likely to go bankrupt may tend to transact with more financial institutions. In reality, at an individual level, a person on the edge of bankruptcy tends to borrow money from multiple lenders. Furthermore, some studies also show the possibility of reverse causality; for instance, Peek and Rosengren (2005) find that firms in poor financial condition are more likely to receive additional bank credit. In addition, Carletti et al. (2007) show that less profitable firms use multiple bank lending more often than profitable ones. Hence, in this section, we verify whether the results obtained in Sect. 3 are from reverse causality. The possibility of reverse causality in this paper may well result from the correlation between the number of correspondent financial institutions and firm weakness. Therefore, if we solve the endogeneity between these two, we can deny the causality that firms that are likely to go bankrupt tend to transact with a greater number of financial institutions. Hence, in this section, we consider the possibility of reverse causality as the problem of endogeneity and clarify the causality between the two.

In addition, in Sect. 3, we only partially control the financial stability of correspondent financial institutions with the credit rating, which is one of the covariates we control. Some studies have argued that financial distress of banks reduces their client firms' investments (e.g., Gibson 1995; Minamihashi 2011). Thus, there is a possibility that the financial health of correspondent financial institutions affects firm bankruptcy. 
Table 4 Results of regression analyses with survival models (with number of correspondent financial institutions)

\begin{tabular}{|c|c|c|c|c|c|c|c|c|}
\hline & $\begin{array}{l}\text { (1) } \\
\text { Cox with std. } \\
\text { err. clustered } \\
\text { by prefecture } \\
\text { and year }\end{array}$ & $\begin{array}{l}(2) \\
\text { Cox with } \\
\text { std. err. } \\
\text { clustered } \\
\text { by firm }\end{array}$ & $\begin{array}{l}\text { (3) } \\
\text { Weibull with } \\
\text { std. err. } \\
\text { clustered by } \\
\text { prefecture } \\
\text { and year }\end{array}$ & $\begin{array}{l}\text { (4) } \\
\text { Weibull } \\
\text { with std. } \\
\text { err. } \\
\text { clustered } \\
\text { by firm }\end{array}$ & $\begin{array}{l}(5) \\
\text { Cox with std. } \\
\text { err. clustered } \\
\text { by prefecture } \\
\text { and year }\end{array}$ & $\begin{array}{l}(6) \\
\text { Cox with } \\
\text { std. err. } \\
\text { clustered } \\
\text { by firm }\end{array}$ & $\begin{array}{l}\text { (7) } \\
\text { Weibull with } \\
\text { std. err. } \\
\text { clustered by } \\
\text { prefecture } \\
\text { and year }\end{array}$ & $\begin{array}{l}(8) \\
\text { Weibull } \\
\text { with std. } \\
\text { err. } \\
\text { clustered } \\
\text { by firm }\end{array}$ \\
\hline \multicolumn{9}{|c|}{ Firm characteristics variables } \\
\hline $\begin{array}{l}\text { Ln (number of } \\
\text { correspondent } \\
\text { financial } \\
\text { institutions) }\end{array}$ & $\begin{array}{l}1.452 * * \\
(0.238)\end{array}$ & $\begin{array}{c}1.452 * \\
(0.283)\end{array}$ & $\begin{array}{l}1.463 * * \\
(0.243)\end{array}$ & $\begin{array}{c}1.463 * \\
(0.288)\end{array}$ & $\begin{array}{l}1.827 * * * \\
(0.340)\end{array}$ & $\begin{array}{l}1.827 * * * \\
(0.402)\end{array}$ & $\begin{array}{l}1.843 * * * \\
(0.347)\end{array}$ & $\begin{array}{l}1.843 * * * \\
(0.408)\end{array}$ \\
\hline City bank & $\begin{array}{c}0.859 \\
(0.440)\end{array}$ & $\begin{array}{c}0.859 \\
(0.437)\end{array}$ & $\begin{array}{c}0.850 \\
(0.437)\end{array}$ & $\begin{array}{c}0.850 \\
(0.435)\end{array}$ & $\begin{array}{c}1.610 \\
(1.204)\end{array}$ & $\begin{array}{c}1.610 \\
(1.210)\end{array}$ & $\begin{array}{c}1.615 \\
(1.212)\end{array}$ & $\begin{array}{c}1.615 \\
(1.217)\end{array}$ \\
\hline Regional bank & $\begin{array}{c}0.730 \\
(0.326)\end{array}$ & $\begin{array}{c}0.730 \\
(0.361)\end{array}$ & $\begin{array}{c}0.727 \\
(0.327)\end{array}$ & $\begin{array}{c}0.727 \\
(0.362)\end{array}$ & $\begin{array}{c}1.277 \\
(0.969)\end{array}$ & $\begin{array}{c}1.277 \\
(0.959)\end{array}$ & $\begin{array}{c}1.281 \\
(0.975)\end{array}$ & $\begin{array}{c}1.281 \\
(0.964)\end{array}$ \\
\hline Shinkin bank & $\begin{array}{c}0.654 \\
(0.319)\end{array}$ & $\begin{array}{c}0.654 \\
(0.330)\end{array}$ & $\begin{array}{c}0.648 \\
(0.318)\end{array}$ & $\begin{array}{c}0.648 \\
(0.329)\end{array}$ & $\begin{array}{c}1.194 \\
(0.905)\end{array}$ & $\begin{array}{c}1.194 \\
(0.901)\end{array}$ & $\begin{array}{c}1.187 \\
(0.903)\end{array}$ & $\begin{array}{c}1.187 \\
(0.899)\end{array}$ \\
\hline Ln (capital) & $\begin{array}{c}1.221 * \\
(0.137)\end{array}$ & $\begin{array}{c}1.221 * \\
(0.134)\end{array}$ & $\begin{array}{c}1.227 * \\
(0.138)\end{array}$ & $\begin{array}{c}1.227 * \\
(0.136)\end{array}$ & $\begin{array}{c}1.103 \\
(0.132)\end{array}$ & $\begin{array}{c}1.103 \\
(0.134)\end{array}$ & $\begin{array}{c}1.111 \\
(0.131)\end{array}$ & $\begin{array}{c}1.111 \\
(0.134)\end{array}$ \\
\hline $\begin{array}{l}\text { Ln (firm } \\
\text { age }+1)\end{array}$ & $\begin{array}{c}1.130 \\
(0.092)\end{array}$ & $\begin{array}{c}1.130 \\
(0.095)\end{array}$ & $\begin{array}{c}1.124 \\
(0.094)\end{array}$ & $\begin{array}{c}1.124 \\
(0.096)\end{array}$ & $\begin{array}{l}1.253 * * \\
(0.126)\end{array}$ & $\begin{array}{l}1.253 * * \\
(0.137)\end{array}$ & $\begin{array}{l}1.253 * * \\
(0.130)\end{array}$ & $\begin{array}{l}1.253 * * \\
(0.140)\end{array}$ \\
\hline $\begin{array}{l}\text { Close } \\
\text { relationship } \\
\text { industries }\end{array}$ & $\begin{array}{c}0.725 \\
(0.164)\end{array}$ & $\begin{array}{c}0.725 \\
(0.163)\end{array}$ & $\begin{array}{c}0.723 \\
(0.165)\end{array}$ & $\begin{array}{c}0.723 \\
(0.164)\end{array}$ & $\begin{array}{c}0.987 \\
(0.260)\end{array}$ & $\begin{array}{c}0.987 \\
(0.272)\end{array}$ & $\begin{array}{c}0.993 \\
(0.267)\end{array}$ & $\begin{array}{c}0.993 \\
(0.278)\end{array}$ \\
\hline Profit & $\begin{array}{l}0.991 * * * \\
(0.003)\end{array}$ & $\begin{array}{l}0.991 * * * \\
(0.003)\end{array}$ & $\begin{array}{l}0.991 * * * \\
(0.003)\end{array}$ & $\begin{array}{l}0.991 * * * \\
(0.003)\end{array}$ & $\begin{array}{l}0.992 * * \\
(0.004)\end{array}$ & $\begin{array}{l}0.992 * * \\
(0.004)\end{array}$ & $\begin{array}{l}0.992 * * \\
(0.004)\end{array}$ & $\begin{array}{l}0.992 * * \\
(0.004)\end{array}$ \\
\hline Ln (sales + 1) & & & & & $\begin{array}{c}1.063 \\
(0.076)\end{array}$ & $\begin{array}{c}1.063 \\
(0.084)\end{array}$ & $\begin{array}{c}1.062 \\
(0.076)\end{array}$ & $\begin{array}{c}1.062 \\
(0.084)\end{array}$ \\
\hline $\begin{array}{l}\text { Ln (manager } \\
\text { age) }\end{array}$ & & & & & $\begin{array}{c}1.124 \\
(0.486)\end{array}$ & $\begin{array}{c}1.124 \\
(0.526)\end{array}$ & $\begin{array}{c}1.095 \\
(0.481)\end{array}$ & $\begin{array}{c}1.095 \\
(0.519)\end{array}$ \\
\hline Ln (offices +1 ) & & & & & $\begin{array}{c}1.296 \\
(0.231)\end{array}$ & $\begin{array}{c}1.296 \\
(0.249)\end{array}$ & $\begin{array}{c}1.324 \\
(0.242)\end{array}$ & $\begin{array}{c}1.324 \\
(0.262)\end{array}$ \\
\hline Ln (employees) & & & & & $\begin{array}{c}1.130 \\
(0.162)\end{array}$ & $\begin{array}{c}1.130 \\
(0.160)\end{array}$ & $\begin{array}{c}1.133 \\
(0.163)\end{array}$ & $\begin{array}{c}1.133 \\
(0.161)\end{array}$ \\
\hline Male & & & & & $\begin{array}{c}1.079 \\
(0.524)\end{array}$ & $\begin{array}{c}1.079 \\
(0.555)\end{array}$ & $\begin{array}{c}1.071 \\
(0.525)\end{array}$ & $\begin{array}{c}1.071 \\
(0.553)\end{array}$ \\
\hline $\begin{array}{l}\text { Ln (credit } \\
\text { rating) }\end{array}$ & & & & & $\begin{array}{l}0.020 * * * \\
(0.013)\end{array}$ & $\begin{array}{l}0.020 * * * \\
(0.015)\end{array}$ & $\begin{array}{l}0.018^{* * * *} \\
(0.013)\end{array}$ & $\begin{array}{l}0.018 * * * \\
(0.014)\end{array}$ \\
\hline \multicolumn{9}{|c|}{ Prefectural characteristics variables } \\
\hline $\begin{array}{l}\text { Herfindahl } \\
\text { index of } \\
\text { financial } \\
\text { institutions }\end{array}$ & $\begin{array}{c}0.001 \\
(0.004)\end{array}$ & $\begin{array}{c}0.001 \\
(0.004)\end{array}$ & $\begin{array}{c}0.001 \\
(0.005)\end{array}$ & $\begin{array}{c}0.001 \\
(0.004)\end{array}$ & $\begin{array}{l}0.000 * \\
(0.000)\end{array}$ & $\begin{array}{l}0.000 * \\
(0.000)\end{array}$ & $\begin{array}{c}0.000 * \\
(0.000)\end{array}$ & $\begin{array}{l}0.000 * * \\
(0.000)\end{array}$ \\
\hline $\begin{array}{l}\text { Ln (financial } \\
\text { institutions) }\end{array}$ & $\begin{array}{c}0.521 \\
(0.618)\end{array}$ & $\begin{array}{c}0.521 \\
(0.534)\end{array}$ & $\begin{array}{c}0.534 \\
(0.633)\end{array}$ & $\begin{array}{c}0.534 \\
(0.548)\end{array}$ & $\begin{array}{c}0.195 \\
(0.288)\end{array}$ & $\begin{array}{c}0.195 \\
(0.245)\end{array}$ & $\begin{array}{c}0.197 \\
(0.294)\end{array}$ & $\begin{array}{c}0.197 \\
(0.250)\end{array}$ \\
\hline Ln (population) & $\begin{array}{c}2.199 \\
(1.762)\end{array}$ & $\begin{array}{c}2.199 \\
(1.560)\end{array}$ & $\begin{array}{c}2.232 \\
(1.799)\end{array}$ & $\begin{array}{c}2.232 \\
(1.596)\end{array}$ & $\begin{array}{c}0.437 \\
(0.388)\end{array}$ & $\begin{array}{c}0.437 \\
(0.372)\end{array}$ & $\begin{array}{c}0.437 \\
(0.391)\end{array}$ & $\begin{array}{c}0.437 \\
(0.377)\end{array}$ \\
\hline
\end{tabular}


Table 4 continued

\begin{tabular}{|c|c|c|c|c|c|c|c|c|}
\hline & $\begin{array}{l}\text { (1) } \\
\text { Cox with std. } \\
\text { err. clustered } \\
\text { by prefecture } \\
\text { and year }\end{array}$ & $\begin{array}{l}\text { (2) } \\
\text { Cox with } \\
\text { std. err. } \\
\text { clustered } \\
\text { by firm }\end{array}$ & $\begin{array}{l}\text { (3) } \\
\text { Weibull with } \\
\text { std. err. } \\
\text { clustered by } \\
\text { prefecture } \\
\text { and year }\end{array}$ & $\begin{array}{l}(4) \\
\text { Weibull } \\
\text { with std. } \\
\text { err. } \\
\text { clustered } \\
\text { by firm }\end{array}$ & $\begin{array}{l}\text { (5) } \\
\text { Cox with std. } \\
\text { err. clustered } \\
\text { by prefecture } \\
\text { and year }\end{array}$ & $\begin{array}{l}\text { (6) } \\
\text { Cox with } \\
\text { std. err. } \\
\text { clustered } \\
\text { by firm }\end{array}$ & $\begin{array}{l}\text { (7) } \\
\text { Weibull with } \\
\text { std. err. } \\
\text { clustered by } \\
\text { prefecture } \\
\text { and year }\end{array}$ & $\begin{array}{l}\text { Weibull } \\
\text { with std. } \\
\text { err. } \\
\text { clustered } \\
\text { by firm }\end{array}$ \\
\hline Ln (GPP) & $\begin{array}{c}3.784 \\
(4.960)\end{array}$ & $\begin{array}{c}3.784 \\
(4.046)\end{array}$ & $\begin{array}{c}3.586 \\
(4.719)\end{array}$ & $\begin{array}{c}3.586 \\
(3.863)\end{array}$ & $\begin{array}{c}3.225 \\
(5.284)\end{array}$ & $\begin{array}{c}3.225 \\
(4.425)\end{array}$ & $\begin{array}{c}3.076 \\
(5.095)\end{array}$ & $\begin{array}{c}3.076 \\
(4.276)\end{array}$ \\
\hline $\begin{array}{l}\text { Ln (ordinary } \\
\text { corporations) }\end{array}$ & $\begin{array}{c}0.108 \\
(0.167)\end{array}$ & $\begin{array}{c}0.108 * \\
(0.136)\end{array}$ & $\begin{array}{c}0.114 \\
(0.176)\end{array}$ & $\begin{array}{c}0.114 * \\
(0.144)\end{array}$ & $\begin{array}{c}0.200 \\
(0.384)\end{array}$ & $\begin{array}{c}0.200 \\
(0.311)\end{array}$ & $\begin{array}{c}0.209 \\
(0.405)\end{array}$ & $\begin{array}{c}0.209 \\
(0.329)\end{array}$ \\
\hline $\begin{array}{l}\text { Economic } \\
\text { growth rate }\end{array}$ & $\begin{array}{c}0.905 * \\
(0.047)\end{array}$ & $\begin{array}{l}0.905 * * * \\
(0.035)\end{array}$ & $\begin{array}{c}0.908 * \\
(0.048)\end{array}$ & $\begin{array}{l}0.908 * * \\
(0.035)\end{array}$ & $\begin{array}{c}0.930 \\
(0.054)\end{array}$ & $\begin{array}{c}0.930 \\
(0.043)\end{array}$ & $\begin{array}{c}0.933 \\
(0.054)\end{array}$ & $\begin{array}{c}0.933 \\
(0.044)\end{array}$ \\
\hline Startup rate & $\begin{array}{c}0.903 \\
(0.181)\end{array}$ & $\begin{array}{c}0.903 \\
(0.143)\end{array}$ & $\begin{array}{c}0.899 \\
(0.179)\end{array}$ & $\begin{array}{c}0.899 \\
(0.143)\end{array}$ & $\begin{array}{c}0.782 \\
(0.184)\end{array}$ & $\begin{array}{c}0.782 \\
(0.161)\end{array}$ & $\begin{array}{c}0.775 \\
(0.183)\end{array}$ & $\begin{array}{c}0.775 \\
(0.160)\end{array}$ \\
\hline $\begin{array}{l}\text { Industry } \\
\text { dummies }\end{array}$ & Yes & Yes & Yes & Yes & Yes & Yes & Yes & Yes \\
\hline $\begin{array}{l}\text { Incorporation } \\
\text { year } \\
\text { dummies }\end{array}$ & Yes & Yes & Yes & Yes & Yes & Yes & Yes & Yes \\
\hline $\begin{array}{l}\text { Log pseudo- } \\
\text { likelihood }\end{array}$ & -942.409 & -942.409 & -597.525 & -597.525 & -673.821 & -673.821 & -445.549 & -445.549 \\
\hline $\begin{array}{l}\text { Number of } \\
\text { observations }\end{array}$ & 2665 & 2665 & 2665 & 2665 & 2620 & 2620 & 2620 & 2620 \\
\hline
\end{tabular}

The upper rows are hazard ratios and the lower rows are standard errors

* Significant at the $10 \%$ level

** Significant at the $5 \%$ level

*** Significant at the $1 \%$ level

Given these considerations, we use the method of instrumental variables (IV methods) to solve these problems. However, IV methods are usually not used in survival analysis; hence, we adopt instrumental variables probit (IV probit) models and a linear probability model (LPM) with the IV methods. ${ }^{7}$ In other words, we analyze the effect of the number of correspondent financial institutions for SMEs at the first settlement on the probability of firm bankruptcy within 5 years of the first settlement.

Here, we explain the instrumental variables used in this paper. As previously mentioned, the number of correspondent financial institutions is suspected to be associated with weakness in firms and their correspondent financial institutions. Hence, we use switching

\footnotetext{
7 The dependent variable in this case is a dummy variable that is equal to 1 if the firm goes bankrupt within 5 years of the first settlement or 0 otherwise.
}

cost, time to the first settlement, the number of offices, and the number of employees as instrumental variables because they may not be associated with weakness in firms and their correspondent financial institutions, and may not directly impact firm bankruptcy.

Switching cost is the cost involved in the switching of firm-bank relationships, and it is likely to be associated with the number of correspondent financial institutions but not with weakness in firms and their correspondent financial institutions. In this paper, we use the product of-ln (financial institutions) and the close relationship industries in Table 4 as the variable expressing the switching cost. The number of financial institutions per firm in each prefecture is negatively associated with the cost involved in the switching; however, as suggested by Sharpe (1990) and Rajan (1992), the cost differs depending on the strength of firm-bank relationships. Therefore, it is not unreasonable to use the product 
Table 5 Results of regression analyses with survival models (with multiple bank relationships dummy variable)

\begin{tabular}{|c|c|c|c|c|c|c|c|c|}
\hline & $\begin{array}{l}\text { Cox with std. } \\
\text { err. clustered } \\
\text { by prefecture } \\
\text { and year }\end{array}$ & $\begin{array}{l}\text { (2) } \\
\text { Cox with } \\
\text { std. err. } \\
\text { clustered } \\
\text { by firm }\end{array}$ & $\begin{array}{l}\text { (3) } \\
\text { Weibull with } \\
\text { std. err. } \\
\text { clustered by } \\
\text { prefecture and } \\
\text { year }\end{array}$ & $\begin{array}{l}\text { (4) } \\
\text { Weibull } \\
\text { with std. } \\
\text { err. } \\
\text { clustered } \\
\text { by firm }\end{array}$ & $\begin{array}{l}\text { Cox with std. } \\
\text { err. clustered } \\
\text { by prefecture } \\
\text { and year }\end{array}$ & $\begin{array}{l}\text { (6) } \\
\text { Cox with } \\
\text { std. err. } \\
\text { clustered } \\
\text { by firm }\end{array}$ & $\begin{array}{l}\text { (7) } \\
\text { Weibull with } \\
\text { std. err. } \\
\text { clustered by } \\
\text { prefecture and } \\
\text { year }\end{array}$ & $\begin{array}{l}(8) \\
\text { Weibull } \\
\text { with std. } \\
\text { err. } \\
\text { clustered } \\
\text { by firm }\end{array}$ \\
\hline \multicolumn{9}{|c|}{ Firm characteristics variables } \\
\hline $\begin{array}{l}\text { Multiple bank } \\
\text { relationships }\end{array}$ & $\begin{array}{l}1.403 * * \\
(0.233)\end{array}$ & $\begin{array}{l}1.403 * \\
(0.269)\end{array}$ & $\begin{array}{l}1.409 * * \\
(0.235)\end{array}$ & $\begin{array}{l}1.409 * \\
(0.272)\end{array}$ & $\begin{array}{l}1.776^{* * * *} \\
(0.388)\end{array}$ & $\begin{array}{l}1.776 * * \\
(0.415)\end{array}$ & $\begin{array}{l}1.784 * * * \\
(0.390)\end{array}$ & $\begin{array}{l}1.784 * * \\
(0.418)\end{array}$ \\
\hline City bank & $\begin{array}{c}0.841 \\
(0.428)\end{array}$ & $\begin{array}{c}0.841 \\
(0.425)\end{array}$ & $\begin{array}{c}0.831 \\
(0.426)\end{array}$ & $\begin{array}{c}0.831 \\
(0.423)\end{array}$ & $\begin{array}{c}1.563 \\
(1.162)\end{array}$ & $\begin{array}{c}1.563 \\
(1.167)\end{array}$ & $\begin{array}{c}1.568 \\
(1.170)\end{array}$ & $\begin{array}{c}1.568 \\
(1.174)\end{array}$ \\
\hline Regional bank & $\begin{array}{c}0.719 \\
(0.321)\end{array}$ & $\begin{array}{c}0.719 \\
(0.354)\end{array}$ & $\begin{array}{c}0.717 \\
(0.322)\end{array}$ & $\begin{array}{c}0.717 \\
(0.355)\end{array}$ & $\begin{array}{c}1.256 \\
(0.946)\end{array}$ & $\begin{array}{c}1.256 \\
(0.935)\end{array}$ & $\begin{array}{c}1.261 \\
(0.954)\end{array}$ & $\begin{array}{c}1.261 \\
(0.942)\end{array}$ \\
\hline Shinkin bank & $\begin{array}{c}0.641 \\
(0.311)\end{array}$ & $\begin{array}{c}0.641 \\
(0.322)\end{array}$ & $\begin{array}{c}0.635 \\
(0.310)\end{array}$ & $\begin{array}{c}0.635 \\
(0.321)\end{array}$ & $\begin{array}{c}1.166 \\
(0.878)\end{array}$ & $\begin{array}{c}1.166 \\
(0.875)\end{array}$ & $\begin{array}{c}1.162 \\
(0.877)\end{array}$ & $\begin{array}{c}1.162 \\
(0.874)\end{array}$ \\
\hline Ln (capital) & $\begin{array}{l}1.235^{*} \\
(0.138)\end{array}$ & $\begin{array}{l}1.235^{*} \\
(0.137)\end{array}$ & $\begin{array}{l}1.241 * \\
(0.138)\end{array}$ & $\begin{array}{l}1.241 * \\
(0.138)\end{array}$ & $\begin{array}{c}1.114 \\
(0.135)\end{array}$ & $\begin{array}{c}1.114 \\
(0.137)\end{array}$ & $\begin{array}{c}1.122 \\
(0.134)\end{array}$ & $\begin{array}{c}1.122 \\
(0.137)\end{array}$ \\
\hline $\begin{array}{l}\text { Ln (firm } \\
\text { age }+1)\end{array}$ & $\begin{array}{c}1.129 \\
(0.093)\end{array}$ & $\begin{array}{c}1.129 \\
(0.095)\end{array}$ & $\begin{array}{c}1.122 \\
(0.094)\end{array}$ & $\begin{array}{c}1.122 \\
(0.096)\end{array}$ & $\begin{array}{l}1.252 * * \\
(0.126)\end{array}$ & $\begin{array}{l}1.252 * * \\
(0.136)\end{array}$ & $\begin{array}{l}1.250 * * \\
(0.129)\end{array}$ & $\begin{array}{l}1.250 * * \\
(0.140)\end{array}$ \\
\hline $\begin{array}{l}\text { Close } \\
\text { relationship } \\
\text { industries }\end{array}$ & $\begin{array}{c}0.732 \\
(0.168)\end{array}$ & $\begin{array}{c}0.732 \\
(0.166)\end{array}$ & $\begin{array}{c}0.730 \\
(0.170)\end{array}$ & $\begin{array}{c}0.730 \\
(0.167)\end{array}$ & $\begin{array}{c}0.995 \\
(0.265)\end{array}$ & $\begin{array}{c}0.995 \\
(0.276)\end{array}$ & $\begin{array}{c}1.002 \\
(0.272)\end{array}$ & $\begin{array}{c}1.002 \\
(0.283)\end{array}$ \\
\hline Profit & $\begin{array}{l}0.991 * * * \\
(0.003)\end{array}$ & $\begin{array}{l}0.991 * * * \\
(0.003)\end{array}$ & $\begin{array}{l}0.991 * * * \\
(0.003)\end{array}$ & $\begin{array}{l}0.991 * * * \\
(0.003)\end{array}$ & $\begin{array}{c}0.992 * \\
(0.004)\end{array}$ & $\begin{array}{c}0.992 * \\
(0.004)\end{array}$ & $\begin{array}{c}0.993 * \\
(0.004)\end{array}$ & $\begin{array}{c}0.993 * \\
(0.004)\end{array}$ \\
\hline Ln (sales + 1) & & & & & $\begin{array}{c}1.063 \\
(0.077)\end{array}$ & $\begin{array}{c}1.063 \\
(0.085)\end{array}$ & $\begin{array}{c}1.062 \\
(0.077)\end{array}$ & $\begin{array}{c}1.062 \\
(0.086)\end{array}$ \\
\hline $\begin{array}{l}\text { Ln (manager } \\
\text { age) }\end{array}$ & & & & & $\begin{array}{c}1.117 \\
(0.487)\end{array}$ & $\begin{array}{c}1.117 \\
(0.525)\end{array}$ & $\begin{array}{c}1.090 \\
(0.484)\end{array}$ & $\begin{array}{c}1.090 \\
(0.520)\end{array}$ \\
\hline $\begin{array}{l}\mathrm{Ln} \\
\quad(\text { offices }+1)\end{array}$ & & & & & $\begin{array}{c}1.318 \\
(0.245)\end{array}$ & $\begin{array}{c}1.318 \\
(0.261)\end{array}$ & $\begin{array}{c}1.341 \\
(0.256)\end{array}$ & $\begin{array}{c}1.341 \\
(0.274)\end{array}$ \\
\hline $\begin{array}{l}\text { Ln } \\
\text { (employees) }\end{array}$ & & & & & $\begin{array}{c}1.157 \\
(0.165)\end{array}$ & $\begin{array}{c}1.157 \\
(0.162)\end{array}$ & $\begin{array}{c}1.160 \\
(0.166)\end{array}$ & $\begin{array}{c}1.160 \\
(0.164)\end{array}$ \\
\hline Male & & & & & $\begin{array}{c}1.057 \\
(0.516)\end{array}$ & $\begin{array}{c}1.057 \\
(0.545)\end{array}$ & $\begin{array}{c}1.051 \\
(0.517)\end{array}$ & $\begin{array}{c}1.051 \\
(0.544)\end{array}$ \\
\hline $\begin{array}{l}\text { Ln (credit } \\
\text { rating) }\end{array}$ & & & & & $\begin{array}{l}0.021^{* * * *} \\
(0.014)\end{array}$ & $\begin{array}{l}0.021 * * * \\
(0.016)\end{array}$ & $\begin{array}{l}0.020 * * * \\
(0.014)\end{array}$ & $\begin{array}{l}0.020 * * * \\
(0.015)\end{array}$ \\
\hline \multicolumn{9}{|c|}{ Prefectural characteristics variables } \\
\hline $\begin{array}{l}\text { Herfindahl } \\
\text { index of } \\
\text { financial } \\
\text { institutions }\end{array}$ & $\begin{array}{c}0.001 \\
(0.004)\end{array}$ & $\begin{array}{c}0.001 \\
(0.004)\end{array}$ & $\begin{array}{c}0.001 \\
(0.005)\end{array}$ & $\begin{array}{c}0.001 \\
(0.004)\end{array}$ & $\begin{array}{c}0.000 * \\
(0.000)\end{array}$ & $\begin{array}{l}0.000 * * \\
(0.000)\end{array}$ & $\begin{array}{l}0.000 * \\
(0.000)\end{array}$ & $\begin{array}{l}0.000 * * \\
(0.000)\end{array}$ \\
\hline $\begin{array}{l}\text { Ln (financial } \\
\text { institutions) }\end{array}$ & $\begin{array}{c}0.540 \\
(0.645)\end{array}$ & $\begin{array}{c}0.540 \\
(0.556)\end{array}$ & $\begin{array}{c}0.552 \\
(0.660)\end{array}$ & $\begin{array}{c}0.552 \\
(0.570)\end{array}$ & $\begin{array}{c}0.206 \\
(0.310)\end{array}$ & $\begin{array}{c}0.206 \\
(0.261)\end{array}$ & $\begin{array}{c}0.209 \\
(0.316)\end{array}$ & $\begin{array}{c}0.209 \\
(0.267)\end{array}$ \\
\hline $\begin{array}{l}\text { Ln } \\
\qquad \text { (population) }\end{array}$ & $\begin{array}{c}2.242 \\
(1.794)\end{array}$ & $\begin{array}{c}2.242 \\
(1.591)\end{array}$ & $\begin{array}{c}2.271 \\
(1.826)\end{array}$ & $\begin{array}{c}2.271 \\
(1.623)\end{array}$ & $\begin{array}{c}0.452 \\
(0.401)\end{array}$ & $\begin{array}{c}0.452 \\
(0.385)\end{array}$ & $\begin{array}{c}0.449 \\
(0.401)\end{array}$ & $\begin{array}{c}0.449 \\
(0.387)\end{array}$ \\
\hline Ln (GPP) & $\begin{array}{c}3.590 \\
(4.728)\end{array}$ & $\begin{array}{c}3.590 \\
(3.850)\end{array}$ & $\begin{array}{c}3.405 \\
(4.502)\end{array}$ & $\begin{array}{c}3.405 \\
(3.681)\end{array}$ & $\begin{array}{c}2.986 \\
(4.929)\end{array}$ & $\begin{array}{c}2.986 \\
(4.128)\end{array}$ & $\begin{array}{c}2.856 \\
(4.767)\end{array}$ & $\begin{array}{c}2.856 \\
(4.006)\end{array}$ \\
\hline $\begin{array}{l}\text { Ln (ordinary } \\
\text { corporations) }\end{array}$ & $\begin{array}{c}0.114 \\
(0.178)\end{array}$ & $\begin{array}{c}0.114 * \\
(0.144)\end{array}$ & $\begin{array}{c}0.120 \\
(0.187)\end{array}$ & $\begin{array}{c}0.120^{*} \\
(0.152)\end{array}$ & $\begin{array}{c}0.215 \\
(0.419)\end{array}$ & $\begin{array}{c}0.215 \\
(0.338)\end{array}$ & $\begin{array}{c}0.225 \\
(0.444)\end{array}$ & $\begin{array}{c}0.225 \\
(0.359)\end{array}$ \\
\hline
\end{tabular}


Table 5 continued

\begin{tabular}{|c|c|c|c|c|c|c|c|c|}
\hline & $\begin{array}{l}\text { (1) } \\
\text { Cox with std. } \\
\text { err. clustered } \\
\text { by prefecture } \\
\text { and year }\end{array}$ & $\begin{array}{l}\text { (2) } \\
\text { Cox with } \\
\text { std. err. } \\
\text { clustered } \\
\text { by firm }\end{array}$ & $\begin{array}{l}\text { (3) } \\
\text { Weibull with } \\
\text { std. err. } \\
\text { clustered by } \\
\text { prefecture and } \\
\text { year }\end{array}$ & $\begin{array}{l}\text { (4) } \\
\text { Weibull } \\
\text { with std. } \\
\text { err. } \\
\text { clustered } \\
\text { by firm }\end{array}$ & $\begin{array}{l}\text { Cox with std. } \\
\text { err. clustered } \\
\text { by prefecture } \\
\text { and year }\end{array}$ & $\begin{array}{l}(6) \\
\text { Cox with } \\
\text { std. err. } \\
\text { clustered } \\
\text { by firm }\end{array}$ & $\begin{array}{l}\text { (7) } \\
\text { Weibull with } \\
\text { std. err. } \\
\text { clustered by } \\
\text { prefecture and } \\
\text { year }\end{array}$ & $\begin{array}{l}(8) \\
\text { Weibull } \\
\text { with std. } \\
\text { err. } \\
\text { clustered } \\
\text { by firm }\end{array}$ \\
\hline $\begin{array}{l}\text { Economic } \\
\text { growth rate }\end{array}$ & $\begin{array}{l}0.904 * \\
(0.047)\end{array}$ & $\begin{array}{l}0.904 * * * \\
(0.035)\end{array}$ & $\begin{array}{c}0.906 * \\
(0.048)\end{array}$ & $\begin{array}{l}0.906 * * \\
(0.035)\end{array}$ & $\begin{array}{c}0.929 \\
(0.054)\end{array}$ & $\begin{array}{c}0.929 \\
(0.044)\end{array}$ & $\begin{array}{c}0.931 \\
(0.054)\end{array}$ & $\begin{array}{c}0.931 \\
(0.044)\end{array}$ \\
\hline Startup rate & $\begin{array}{c}0.898 \\
(0.180)\end{array}$ & $\begin{array}{c}0.898 \\
(0.142)\end{array}$ & $\begin{array}{c}0.894 \\
(0.179)\end{array}$ & $\begin{array}{c}0.894 \\
(0.142)\end{array}$ & $\begin{array}{c}0.778 \\
(0.182)\end{array}$ & $\begin{array}{c}0.778 \\
(0.159)\end{array}$ & $\begin{array}{c}0.771 \\
(0.181)\end{array}$ & $\begin{array}{c}0.771 \\
(0.158)\end{array}$ \\
\hline $\begin{array}{l}\text { Industry } \\
\text { dummies }\end{array}$ & Yes & Yes & Yes & Yes & Yes & Yes & Yes & Yes \\
\hline $\begin{array}{l}\text { Incorporation } \\
\text { year } \\
\text { dummies }\end{array}$ & Yes & Yes & Yes & Yes & Yes & Yes & Yes & Yes \\
\hline $\begin{array}{c}\text { Log pseudo- } \\
\text { likelihood }\end{array}$ & -942.712 & -942.712 & -597.857 & -597.857 & -674.178 & -674.178 & -445.961 & -445.961 \\
\hline $\begin{array}{l}\text { Number of } \\
\text { observations }\end{array}$ & 2665 & 2665 & 2665 & 2665 & 2620 & 2620 & 2620 & 2620 \\
\hline
\end{tabular}

The upper rows are hazard ratios and the lower rows are standard errors

* Significant at the $10 \%$ level

** Significant at the $5 \%$ level

*** Significant at the $1 \%$ level

of these two variables as a proxy variable for the switching cost. ${ }^{8}$

In addition, the time to the first settlement is a continuous variable that shows time intervals between the incorporation and the first settlement of firms, and the unit of this variable is 1 year. In the sample firms, even if the time of incorporation is the same, the time to the first settlement is not necessarily the same. For example, some of the firms' time interval between incorporation and the first settlement is 1 year, but it is half a year for others. The longer the interval, the more opportunities there are for firms to transact with many financial institutions; thus, this variable is likely to be positively associated with the number of correspondent financial institutions but not with weakness in firms and their correspondent financial institutions.

Furthermore, the number of offices and the number of employees are also likely to satisfy the conditions of

\footnotetext{
${ }^{8}$ In this paper, it is not to measure switching cost very accurately but to find valid instrumental variables that matters, and the product of these two satisfies the conditions of instrumental variables. Thus, even if the product of these two does not accurately correspond to the cost involved in the switching of firm-bank relationships, it does not mean that the product of the two is inappropriate as an instrumental variable.
}

instrumental variables because of the following reasons: First, these variables in this paper are not widely distributed, and thus these variables are highly likely not to have a strong association with firm weakness, not to mention weakness in their correspondent financial institutions. For the same reason, these variables may well not directly affect firm bankruptcy. Finally, although the distributions of these variables are narrow, they are supposed to have a certain correlation with the number of correspondent financial institutions.

Hence, in this paper, we adopt these four instrumental variables for the number of correspondent financial institutions and examine the effect of the number of correspondent financial institutions on the probability of firm bankruptcy within 5 years of the first settlement.

Tables 6 and 7 show the results of the regression analyses with the IV probit models; concretely, Table 6 shows the result of using the maximum likelihood estimation, and Table 7 shows the results of using Newey's (1987) two-step estimation. In Table 6, column 1 shows the results when we use standard errors clustered by prefecture and settlement year, while column 2 represents the results when we use 
Table 6 Results of regression analyses with IV probit models (maximum likelihood estimation)

\begin{tabular}{|c|c|c|c|c|c|c|c|c|}
\hline & \multicolumn{4}{|c|}{ (1) Clustered by prefecture and year } & \multicolumn{4}{|c|}{ (2) Clustered by firm } \\
\hline & $\mathrm{d} y / \mathrm{d} x$ & $\begin{array}{l}\text { Delta-method } \\
\text { SE }\end{array}$ & $z$ & $P>|z|$ & $\mathrm{d} y / \mathrm{d} x$ & $\begin{array}{l}\text { Delta-method } \\
\text { SE }\end{array}$ & $z$ & $P>|z|$ \\
\hline \multicolumn{9}{|l|}{ Firm characteristics variables } \\
\hline $\begin{array}{l}\text { Ln (number of correspondent } \\
\text { financial institutions) }\end{array}$ & $1.238 * * *$ & 0.442 & 2.800 & 0.005 & $1.238 * * *$ & 0.426 & 2.900 & 0.004 \\
\hline City bank & 0.292 & 0.305 & 0.960 & 0.339 & 0.292 & 0.303 & 0.960 & 0.336 \\
\hline Regional bank & 0.247 & 0.304 & 0.810 & 0.415 & 0.247 & 0.297 & 0.830 & 0.405 \\
\hline Shinkin bank & 0.237 & 0.305 & 0.780 & 0.436 & 0.237 & 0.302 & 0.790 & 0.432 \\
\hline Ln (capital) & 0.028 & 0.059 & 0.470 & 0.637 & 0.028 & 0.057 & 0.490 & 0.627 \\
\hline Ln (firm age + 1) & 0.058 & 0.041 & 1.420 & 0.157 & 0.058 & 0.046 & 1.260 & 0.209 \\
\hline Close relationship industries & -0.152 & 0.116 & -1.310 & 0.190 & -0.152 & 0.121 & -1.250 & 0.210 \\
\hline Profit & $-0.007 * * *$ & 0.002 & -2.980 & 0.003 & $-0.007 * * *$ & 0.002 & -3.210 & 0.001 \\
\hline Ln $($ sales +1$)$ & 0.008 & 0.027 & 0.280 & 0.783 & 0.008 & 0.029 & 0.260 & 0.796 \\
\hline Ln (manager age) & 0.067 & 0.185 & 0.360 & 0.717 & 0.067 & 0.189 & 0.350 & 0.723 \\
\hline Male & 0.017 & 0.203 & 0.080 & 0.933 & 0.017 & 0.214 & 0.080 & 0.937 \\
\hline Ln (credit rating) & $-1.883 * * *$ & 0.310 & -6.070 & 0.000 & $-1.883 * * *$ & 0.372 & -5.060 & 0.000 \\
\hline $\begin{array}{l}\text { Prefectural characteristics } \\
\text { variables Herfindahl index of } \\
\text { financial } \\
\text { institutions }\end{array}$ & -5.170 & 3.232 & -1.600 & 0.110 & $-5.170^{*}$ & 2.993 & -1.730 & 0.084 \\
\hline Ln (financial institutions) & -0.685 & 0.586 & -1.170 & 0.243 & -0.685 & 0.497 & -1.380 & 0.168 \\
\hline Ln (population) & -0.209 & 0.353 & -0.590 & 0.554 & -0.209 & 0.334 & -0.630 & 0.532 \\
\hline $\operatorname{Ln}(\mathrm{GPP})$ & 0.420 & 0.645 & 0.650 & 0.515 & 0.420 & 0.543 & 0.770 & 0.439 \\
\hline Ln (ordinary corporations) & -0.633 & 0.753 & -0.840 & 0.400 & -0.633 & 0.611 & -1.040 & 0.300 \\
\hline Economic growth rate & -0.043 & 0.026 & -1.630 & 0.104 & $-0.043 * *$ & 0.020 & -2.110 & 0.035 \\
\hline Startup rate & -0.141 & 0.091 & -1.550 & 0.120 & $-0.141 *$ & 0.081 & -1.750 & 0.081 \\
\hline Industry dummies & Yes & & & & Yes & & & \\
\hline Incorporation year dummies & Yes & & & & Yes & & & \\
\hline Log pseudo-likelihood & -1945.835 & & & & 1945.835 & & & \\
\hline Wald test of exogeneity & 0.070 & & & & 0.064 & & & \\
\hline Number of observations & 2621 & & & & 2621 & & & \\
\hline
\end{tabular}

* Significant at the $10 \%$ level

** Significant at the $5 \%$ level

*** Significant at the $1 \%$ level

standard errors clustered by firm. As shown in these columns, more correspondent financial institutions at the first settlement increase the probability of firm bankruptcy during 5 years from the first settlement at the $1 \%$ significance level. Moreover, although the Wald tests of exogeneity are rejected at the $10 \%$ significance level, they are not rejected at the $5 \%$ significance level; hence, there is a high probability that the number of correspondent financial institutions, in this case, is not endogenous.
In addition, in Table 7, we obtain similar results as in Table 6; specifically, more correspondent financial institutions at the first settlement increase the probability of firm bankruptcy within 5 years of the first settlement at the $5 \%$ significance level, and the Wald test of exogeneity is not rejected at the $5 \%$ significance level. Moreover, column A shows that the coefficient on the credit rating is positive and significant. This indicates that the lower the risk, the more the firms transact with financial institutions. Thus, this 
Table 7 Results of regression analyses with IV probit models (two - step estimation)

\begin{tabular}{|c|c|c|c|c|c|c|c|c|}
\hline & \multicolumn{4}{|c|}{$\begin{array}{l}\text { (A) First-stage regression } \\
\text { Dependent variable: Ln } \\
\text { (number of financial institutions) }\end{array}$} & \multicolumn{4}{|c|}{$\begin{array}{l}\text { (B) Two-step probit with endogenous } \\
\text { regressors } \\
\text { Dependent variable: Bankruptcy }\end{array}$} \\
\hline & Coefficient & SE & $t$ & $P>|z|$ & $\mathrm{d} y / \mathrm{d} x$ & $\begin{array}{l}\text { Delta- } \\
\text { method } \\
\text { SE }\end{array}$ & $z$ & $P>|z|$ \\
\hline \multicolumn{9}{|l|}{ Firm characteristics variables } \\
\hline $\begin{array}{l}\text { Ln (number of correspondent financial } \\
\text { institutions) }\end{array}$ & & & & & $1.363 * *$ & 0.581 & 2.350 & 0.019 \\
\hline Switching cost & 0.052 & 0.045 & 1.150 & 0.249 & & & & \\
\hline Time to the first settlement & -0.007 & 0.028 & -0.240 & 0.809 & & & & \\
\hline Ln (offices + 1) & $0.070 * * *$ & 0.021 & 3.330 & 0.001 & & & & \\
\hline Ln (employees) & $0.079 * * *$ & 0.011 & 7.180 & 0.000 & & & & \\
\hline City bank & $-0.116^{* *}$ & 0.054 & -2.160 & 0.031 & 0.322 & 0.339 & 0.950 & 0.342 \\
\hline Regional bank & $-0.151 * * *$ & 0.050 & -3.000 & 0.003 & 0.272 & 0.335 & 0.810 & 0.416 \\
\hline Shinkin bank & $-0.147 * * *$ & 0.053 & -2.790 & 0.005 & 0.262 & 0.343 & 0.760 & 0.446 \\
\hline Ln (capital) & $0.027 * * *$ & 0.009 & 3.020 & 0.003 & 0.031 & 0.063 & 0.490 & 0.621 \\
\hline Ln (firm age + 1) & 0.014 & 0.010 & 1.480 & 0.139 & 0.065 & 0.056 & 1.140 & 0.253 \\
\hline Close relationship industries & $0.127 * * *$ & 0.023 & 5.420 & 0.000 & -0.167 & 0.150 & -1.110 & 0.265 \\
\hline Profit & $0.001 * *$ & 0.001 & 2.420 & 0.016 & $-0.007 * * *$ & 0.002 & -3.560 & 0.000 \\
\hline $\operatorname{Ln}($ sales +1$)$ & $0.013 * * *$ & 0.004 & 3.200 & 0.001 & 0.009 & 0.027 & 0.320 & 0.750 \\
\hline Ln (manager age) & -0.038 & 0.039 & -0.970 & 0.331 & 0.074 & 0.223 & 0.330 & 0.741 \\
\hline Male & 0.028 & 0.038 & 0.740 & 0.461 & 0.019 & 0.238 & 0.080 & 0.936 \\
\hline Ln (credit rating) & $0.196 * *$ & 0.083 & 2.360 & 0.018 & $-2.080 * * *$ & 0.437 & -4.760 & 0.000 \\
\hline $\begin{array}{l}\text { Prefectural characteristics variables Herfindahl } \\
\text { index of financial institutions }\end{array}$ & 0.582 & 0.458 & 1.270 & 0.204 & $-5.710^{*}$ & 2.916 & -1.960 & 0.050 \\
\hline Ln (financial institutions) & $0.216 * *$ & 0.092 & 2.360 & 0.018 & -0.756 & 0.582 & -1.300 & 0.194 \\
\hline Ln (GPP) & -0.031 & 0.100 & -0.310 & 0.754 & 0.465 & 0.594 & 0.780 & 0.434 \\
\hline Ln (ordinary corporations) & 0.110 & 0.114 & 0.970 & 0.333 & -0.699 & 0.701 & -1.000 & 0.318 \\
\hline Economic growth rate & 0.007 & 0.004 & 1.630 & 0.104 & $-0.047 * *$ & 0.023 & -2.050 & 0.040 \\
\hline Startup rate & 0.007 & 0.013 & 0.580 & 0.559 & $-0.155^{*}$ & 0.081 & -1.910 & 0.056 \\
\hline Constant & $-0.820 *$ & 0.451 & -1.820 & 0.069 & & & & \\
\hline Industry dummies & Yes & & & & & & & \\
\hline Incorporation year dummies & Yes & & & & & & & \\
\hline Adjusted R-squared & 0.116 & & & & & & & \\
\hline Wald test of exogeneity & 0.071 & & & & & & & \\
\hline Number of observations & 2621 & & & & & & & \\
\hline
\end{tabular}

* Significant at the $10 \%$ level

** Significant at the $5 \%$ level

*** Significant at the $1 \%$ level

result supports the causality that more correspondent financial institutions increase subsequent firm bankruptcy risk.

Table 8 shows the results of using the LPM with the IV methods. Columns 1 and 2 show the results of using two stage least squares (2SLS) estimators, and columns 3 and 4 show those of using the generalized method of moments (GMM) estimators. This table also shows that more correspondent financial institutions increase the probability of firm bankruptcy, and the 


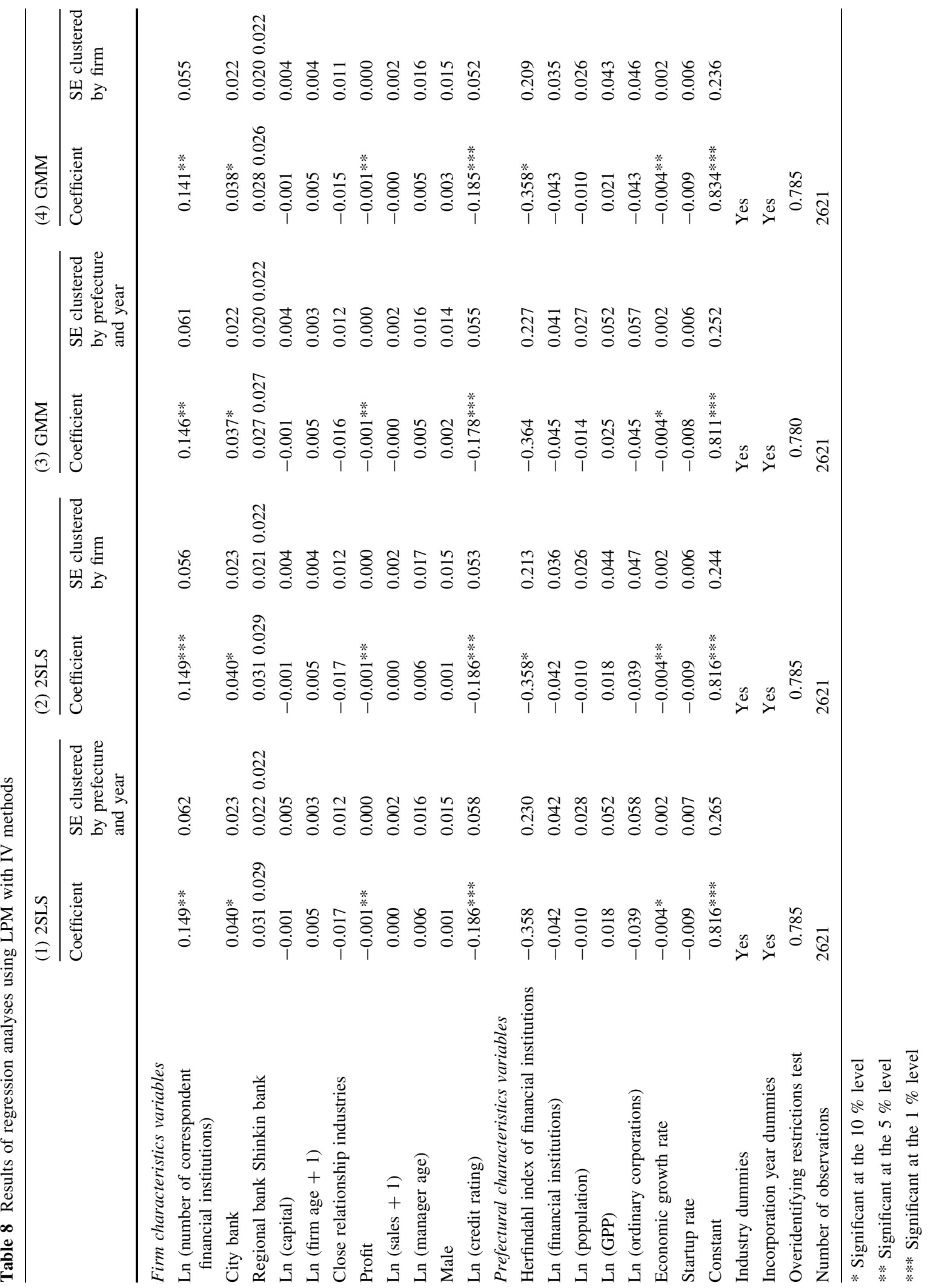


overidentifying restrictions tests are not rejected at the $10 \%$ significance level in columns $1-4$; thus, there is a high probability that the number of correspondent financial institutions, in this case, is not endogenous.

As shown in this section, which considers the possibility of reverse causality and the problem of endogeneity, we obtain the results that the increase in the number of correspondent financial institutions increases the risk of firm bankruptcy, and this result corresponds to that obtained in the previous section. Therefore, the results in the previous section have a high level of robustness.

\section{Conclusion}

As indicated, more correspondent financial institutions for SMEs at the first settlement increase the risk of subsequent firm bankruptcy, and we confirmed the causality between the two. This result corresponds to previous empirical studies such as Degryse and Ongena (2001) and Castelli et al. (2012), and the theoretical studies by Olson (1965) and Osborne (2003). This paper offers a new management strategy to reduce the risk of firm bankruptcy in the early stages of the entrepreneurial process. In addition, the enterprise information at the first settlement of accounts is the very first piece of information about firms that we can obtain. Hence, the findings in this paper indicate the possibility that the number of correspondent financial institutions at the first settlement functions as an indicator of the future of young SMEs, and this can also be useful to investors.

However, this paper only examines the effect of the number of correspondent financial institutions for SMEs at the first settlement on the subsequent firm bankruptcy risk. Thus, this paper does not show that more correspondent financial institutions always make against SMEs. In fact, some studies have argued that the number of correspondent financial institutions is positively associated with firms' growth opportunities (e.g., Houston and James 1996; Farinha and Santos 2002). In addition, as previously mentioned, we target only those firms that transact with at least one financial institution and disclose information about profit at the first settlement. Therefore, the impact on firms that do not correspond to the above description remains outside the scope of the analyses in this paper. Moreover, as Beck et al. (2014) show, the lending activities of financial institutions are related to business cycles. Unfortunately, this is also beyond the scope of this paper; hence, we need to deepen discussions on the issues using more detailed data over longer durations.

Acknowledgments I would like to thank László Szerb (associate editor), two anonymous referees, Mohammad Hoque, Jiro Nemoto, Yoshiaki Ogura, Arito Ono, Tadashi Sonoda, Hirofumi Uchida, Kaoru Ueda, Nobuyoshi Yamori, Junji Yano, as well as the participants at the Annual Tokyo Business Research Conference, the 2nd Chubu Area Study Group of the Japan Society of Monetary Economics in 2014, the Monetary Economics Workshop, the 2015 Spring Annual Meeting of the Japan Society of Monetary Economics, the 2015 Spring Meeting of the Japanese Economic Association, and the SIBR 2015 Osaka Conference on Interdisciplinary Business \& Economics Research for their helpful comments. I am also grateful to Leo Iijima, Graduate Program for RealWorld Data Circulation Leaders, which is one of the Nagoya University Leading Graduate School Programs, and Tokyo Shoko Research, Ltd. for data provision. All remaining errors are my own responsibility. I acknowledge financial support from the Research Fellowships for Young Scientists of the Japan Society for the Promotion of Science (JSPS) through a Grant-inAid for JSPS Fellows 15J00987.

Open Access This article is distributed under the terms of the Creative Commons Attribution 4.0 International License (http:// creativecommons.org/licenses/by/4.0/), which permits unrestricted use, distribution, and reproduction in any medium, provided you give appropriate credit to the original author(s) and the source, provide a link to the Creative Commons license, and indicate if changes were made.

\section{Appendix}

This "Appendix" describes the theoretical model to show that the increase in the number of correspondent financial institutions increases the risk of firm bankruptcy. Let us assume the following case. The number of correspondent financial institutions of a firm is $n$ and each financial institution has two strategies: Support and Don't support. Moreover, when the number of financial institutions that choose Support is $w$ or greater, bankruptcy of the firm can be avoided, where $1 \leq w \leq n$. Furthermore, if bankruptcy of the firm is avoided, then all $n$ correspondent financial institutions can obtain a benefit $b .{ }^{9}$ However, financial

\footnotetext{
${ }^{9}$ In this case, $b$ expresses the future margin of profits on lending that the financial institutions can earn by avoiding the firm's bankruptcy.
} 
institutions that choose Support have to pay cost $c$. Therefore, the net profits of the financial institutions that choose Support are represented by $b-c .{ }^{10}$ On the other hand, when the number of financial institutions that choose Support is less than $w$, the firm goes bankrupt. In brief, in this paper, we assume a vulnerable firm whose bankruptcy largely depends on whether it can receive support from its correspondent financial institutions.

Next, we consider the Nash equilibrium in this model. In this case, a group of correspondent financial institutions is considered to be a temporary combination. Hence, in this case, it is appropriate to assume that the Nash equilibrium is a symmetric one.

The case of $w=1$, i.e., the state when a specific financial institution chooses Support, is not the Nash equilibrium because $b \geq b-c$. Hence, we consider the Nash equilibrium while including a mixed strategy, and assume the case where all correspondent financial institutions choose Don't support with the same probability $p$, as in the Nash equilibrium. Because of the fundamental principle of the mixed strategy, the benefits when a correspondent financial institution chooses Support with the probability of 1 and when it chooses Don't support with the probability of 1 have to be equal. When it chooses Support, the benefit is $b-c$ because the bankruptcy of the firm can be avoided, irrespective of other correspondent financial institutions' actions. ${ }^{11}$ If it chooses Don't Support while other correspondent financial institutions choose Support, then it can gain benefit $b$. However, if all other correspondent financial institutions also choose Don't support, the benefit is 0 . In this case, the probability that all other correspondent financial institutions choose Don't support is $p^{n-1}$; hence, the probability that at least one of the other correspondent financial institutions chooses Support is $1-p^{n-1}$. Therefore, the condition for when all correspondent financial institutions choose Don't support with the probability of $p$ is the Nash equilibrium, shown in Eq. (1) as follows:

\footnotetext{
$\overline{{ }^{10} \text { Where } b-c}>0$. If we assume $b-c \leq 0$, the Nash equilibrium is the state when all correspondent financial institutions choose Don't support.

11 In this paper, we use young and small firms as a sample. Therefore, the bankruptcy of the firms can be avoided if at least one of the correspondent financial institutions chooses Support, and thus it can gain the benefit $b-c$, regardless of the actions of other correspondent financial institutions.
}

$b-c=\left(1-p^{n-1}\right) b$.

Equation (2) solves this for $p$ :

$p=\left(\frac{c}{b}\right)^{\frac{1}{n-1}}$.

To the contrary, when all correspondent financial institutions choose Don't support with this probability, the expected profit of each correspondent financial institution is $b-c$ which is equal to the expected profit in the case where a correspondent financial institution chooses Support. As mentioned above, there is no strategy available for any of the correspondent financial institutions other than Support or Don't support; hence, the state where all correspondent financial institutions choose Don't support with the probability of $p=\left(\frac{c}{b}\right)^{\frac{1}{n-1}}$ is a unique symmetric Nash equilibrium. Moreover, the probability that each correspondent financial institution chooses Don't support increases with $n$ because $\frac{c}{b}<1$. In brief, the probability that each correspondent financial institution chooses Don't support increases with the number of correspondent financial institutions. Furthermore, the probability that all correspondent financial institutions choose Don't support is represented by Eq. (3) as follows:

$p^{n}=\left(\frac{c}{b}\right)^{\frac{n}{n-1}}$.

This probability also increases with $n$. Therefore, the increase in the number of correspondent financial institutions increases the free rider to other correspondent financial institutions, and thus firm bankruptcy is more likely to occur.

\section{References}

Beck, T., Degryse, H., Haas, R., \& Horen, N. (2014). When arm's length is too far: Relationship banking over the business cycle. In EBRD working paper, 169.

Bolton, P., \& Scharfstein, D. (1996). Optimal debt structure and the number of creditors. Journal of Political Economy, 104, 1-25. doi:10.1086/262015.

Brunner, A., \& Krahnen, J. (2008). Multiple lenders and corporate distress: Evidence on debt restructuring. Review of Economic Studies, 75, 415-442. doi:10.1111/j.1467-937X. 2008.00483.x.

Carletti, E., Cerasi, V., \& Daltung, S. (2007). Multiple-bank lending: Diversification and free-riding in monitoring. Journal of Financial Intermediation, 16, 425-451. doi:10. 1016/j.jfi.2007.03.001. 
Carter, R., \& Van Auken, H. (2006). Small firm bankruptcy. Journal of Small Business Management, 44, 493-512. doi:10.1111/j.1540-627X.2006.00187.x.

Castelli, A., Dwyer, G., \& Hasan, I. (2012). Bank relationships and firms' financial performance: The Italian experience. European Financial Management, 18, 28-67. doi:10.1111/ j.1468-036X.2009.00531.X.

Degryse, H., \& Ongena, S. (2001). Bank relationships and firm profitability. Financial Management, 30, 9-34. doi:10. 2307/3666389.

Detragiache, E., Garella, P., \& Guiso, L. (2000). Multiple versus single banking relationships: Theory and evidence. Journal of Finance, 55, 1133-1161. doi:10.1111/0022-1082.00243.

Dewatripont, M., \& Maskin, E. (1995). Credit and efficiency in centralized and decentralized economies. Review of Economic Studies, 62, 541-555. doi:10.2307/2298076.

Farinha, L., \& Santos, J. (2002). Switching from single to multiple bank lending relationships: Determinants and implications. Journal of Financial Intermediation, 11, 124-151. doi:10.1006/jfin.2001.0328.

Foglia, A., Laviola, S., \& Reedtz, P. (1998). Multiple banking relationships and the fragility of corporate borrowers. Journal of Banking \& Finance, 22, 1441-1456. doi:10. 1016/S0378-4266(98)00058-2.

Franco, M., \& Haase, H. (2010). Failure factors in small and medium-sized enterprises: Qualitative study from an attributional perspective. International Entrepreneurship and Management Journal, 6, 503-521. doi:10.1007/s11365009-0124-5.

Gambini, A., \& Zazzaro, A. (2013). Long-lasting bank relationships and growth of firms. Small Business Economics, 40, 977-1007. doi:10.1007/s11187-011-9406-8.

Gibson, M. (1995). Can bank health affect investment? Evidence from Japan. Journal of Business, 68, 281-308. doi:10.1086/296666.

Grunert, J., \& Weber, M. (2009). Recovery rates of commercial lending: Empirical evidence for German companies. Journal of Banking \& Finance, 33, 505-513. doi:10.1016/ j.jbankfin.2008.09.002.

Guiso, L., \& Minetti, R. (2010). The structure of multiple credit relationships: Evidence from U.S. firms. Journal of Money, Credit and Banking, 42, 1037-1071. doi:10.1111/j.15384616.2010.00319.x.

Han, L., Benson, A., Chen, J. J. H., \& Zhang, S. (2014). The use and impacts of bank support on UK small and mediumsized enterprises. International Small Business Journal, 32, 61-80. doi:10.1177/0266242612455008.

Hernández-Cánovas, G., \& Martínez-Solano, P. (2007). Effect of the number of banking relationships on credit availability: Evidence from panel data of Spanish small firms. Small Business Economics, 28, 37-53. doi:10.1007/ s11187-005-6704-z.

Hoshi, T., Kashyap, A., \& Scharfstein, D. (1990). The role of banks in reducing the costs of financial distress in Japan.
Journal of Financial Economics, 27, 67-88. doi:10.1016/ 0304-405X(90)90021-Q.

Houston, J., \& James, C. (1996). Bank information monopolies and the mix of private and public debt claims. Journal of Finance, 51, 1863-1889. doi:10.2307/2329541.

Mata, J. (1994). Firm growth during infancy. Small Business Economics, 6, 27-39. doi:10.1007/BF01066110.

Mayer, C. (1988). New issues in corporate finance. European Economic Review, 32, 1167-1189. doi:10.1016/00142921(88)90077-3.

Minamihashi, N. (2011). Credit crunch caused by bank failures and self-selection behavior in lending markets. Journal of Money, Credit and Banking, 43, 133-161. doi:10.1111/j. 1538-4616.2010.00368.x.

Newey, W. (1987). Efficient estimation of limited dependent variable models with endogenous explanatory variables. Journal of Econometrics, 36, 231-250. doi:10.1016/03044076(87)90001-7.

Ogura, Y. (2007). Lending competition in regional financial market and credit availability for entrepreneurs. In Y. Tsutsui \& S. Uemura (Eds.), Relationship Banking and Regional Finance (pp. 81-100). Tokyo: Nikkei Publishing Inc.

Olson, M. (1965). The logic of collective action: Public goods and the theory of groups. Massachusetts: Harvard University Press.

Ongena, S., \& Smith, D. (2000). What determines the number of bank relationships? Cross-country evidence. Journal of Financial Intermediation, 9, 26-56. doi:10.1006/jfin.1999. 0273 .

Osborne, M. (2003). An Introduction to game theory. Oxford: Oxford University Press.

Peek, J., \& Rosengren, E. (2005). Unnatural selection: Perverse incentives and the misallocation of credit in Japan. American Economic Review, 95, 1144-1166. doi:10.1257/ 0002828054825691.

Petersen, M., \& Rajan, R. (1994). The benefits of lending relationships: Evidence from small business data. Journal of Finance, 49, 3-37. doi:10.2307/2329133.

Rajan, R. (1992). Insiders and outsiders: The choice between informed and arm's-length debt. Journal of Finance, 47, 1367-1400. doi:10.2307/2328944.

Sharpe, S. (1990). Asymmetric information, bank lending and implicit contracts: A stylized model of customer relationships. Journal of Finance, 45, 1069-1087. doi:10.2307/ 2328715.

Shimizu, K. (2012). Bankruptcies of small firms and lending relationship. Journal of Banking \& Finance, 36, 857-870. doi:10.1016/j.jbankfin.2011.09.016.

Song, M., Podoynitsyna, K., van der Bij, H., \& Halman, J. I. M. (2008). Success factors in new ventures: A meta-analysis. Journal of Product Innovation Management, 25, 7-27. 